Title page: Coagulation abnormalities in children with uncorrected congenital heart defects seen at a teaching hospital in a developing country.

Short title: Coagulation abnormalities in children with uncorrected congenital heart defects

Authors: Omotola O. Majiyagbe ${ }^{1,2}$, Adeseye M. Akinsete ${ }^{1,3}$, Titilayo A. Adeyemo, Ekanem N. Ekure ${ }^{1,3}$, Christy A. N. Okoromah ${ }^{1,3}$.

${ }^{1}$ Department of Paediatrics, Lagos University Teaching Hospital, Idi-Araba, Lagos, Nigeria.

${ }^{2}$ Department of Paediatrics, Massey Street Children's hospital, Lagos Island, Lagos, Nigeria.

${ }^{3}$ Department of Paediatrics, College of Medicine of the University of Lagos, Idi-Araba, Lagos, Nigeria.

${ }^{4}$ Department of Pathology, College of Medicine of the University of Lagos, Idi-Araba, Lagos, Nigeria.

Current address: Department of Paediatrics, Massey Street Children's hospital, Lagos Island, Lagos,

Nigeria.

*Corresponding author

E-mail: omotolamajiyagbe@yahoo.com (OM)

\title{
Contributor Role
}

\section{Omotola O. Majiyagbe}

ROLES: Conceptualization, Data curation, Formal analysis, Investigation, Methodology, Project administration, Resources, Writing - original draft, Writing - review \& editing

\section{Adeseye M. Akinsete}

ROLES: Methodology, Project administration, Supervision, Writing - review \& editing

\section{Titilayo A. Adeyemo}

ROLES: Methodology, Project administration, Resources, Supervision, Validation, Writing - review \& editing

\section{Ekanem N. Ekure}

ROLES: Conceptualization, Methodology, Project administration, Resources, Supervision, Writing - original draft, Writing - review \& editing

\section{Christy A. N. Okoromah}

NOTE: This preprint reports new research that has not been certified by peer review and should not be used to guide clinical practice. 
medRxiv preprint doi: https://doi.org/10.1101/2022.01.31.22270219; this version posted February 1, 2022. The copyright holder for this preprint (which was not certified by peer review) is the author/funder, who has granted medRxiv a license to display the preprint in perpetuity.

It is made available under a CC-BY 4.0 International license.

ROLES: Supervision, Writing-review \& editing.

Competing interests: The authors have declared that no competing interests exist.

\section{Abstract}




\section{Background}

Coagulation abnormality is a significant complication and cause of mortality in children with uncorrected congenital heart defects (CHD). The aim of this study was to determine the prevalence of coagulation abnormalities and the associated factors in children with uncorrected CHD.

\section{Method}

A cross sectional study conducted to determine the prevalence of coagulation abnormalities among 70 children with uncorrected CHD aged six months to 17 years and 70 age and sex matched apparently healthy controls. Coagulation abnormality was determined using complete blood count, prothrombin time, activated partial thromboplastin time and D-dimer assay.

\section{Results}

The prevalence of coagulation abnormalities among children with CHD and controls was $37.1 \%$ and $7.1 \%$ respectively. Children with Cyanotic CHD had a significantly higher prevalence of coagulation abnormalities compared to children with Acyanotic CHD (57.1\% versus $17.1 \%$ ). Haematocrit and oxygen saturation levels were significantly associated with coagulation abnormalities.

\section{Conclusion}

This study affirms that coagulation abnormality is high in children with uncorrected CHD. Oxygen saturation and haematocrit are factors of coagulation abnormalities. Routine coagulation screening is recommended especially in children with cyanotic congenital heart defects to improve their quality of life and reduce morbidity and mortality while awaiting definitive surgeries. 
medRxiv preprint doi: https://doi.org/10.1101/2022.01.31.22270219; this version posted February 1, 2022. The copyright holder for this preprint (which was not certified by peer review) is the author/funder, who has granted medRxiv a license to display the preprint in perpetuity.

It is made available under a CC-BY 4.0 International license. 


\section{Introduction}

Globally, congenital heart defect (CHD) defined as a structural and functional defect of the heart present at birth, affecting the heart or adjacent great blood vessels, detected either at birth or later in life, accounts for nearly a third of all major congenital anomalies with an estimated prevalence of 8-12 per 1000 live births.[1,2,3]

In Nigeria, the estimated prevalence varies from 4.6 - 9.3 per 1000 children.[4,5] The prevalence of uncorrected CHD, growing to adulthood in Nigeria is unknown, however, in some developed countries like United States, $85 \%$ of children with CHD are documented to survive into adulthood since the advent of neonatal repair of complex heart lesions.[6] A multi-center hospital survey in Nigeria by Ekure et al [7] in 2017 reported that $84 \%$ of the enrolled 1,296 children with CHD still had uncorrected lesions. The delay in corrective surgery was due to late presentation, inadequate infrastructure as well as a high cost of cardiac care. Morbidity from uncorrected CHD may be due to anaemia, infections, malnutrition, congestive cardiac failure, coagulation abnormalities, cerebrovascular accident, bleeding diathesis and pulmonary hypertension, which can have a devastating effect on their quality of life.[8]

Coagulation defined as a physiologic process of maintaining haemostasis in the body, can be disrupted in children with CHD leading to functional and structural abnormalities. This is usually due to the chronic state of hypoxia in CCHD as well as chronic heart failure in children with ACHD. These mechanisms lead to compensatory erythrocytosis, hyperviscosity, thrombocytopaenia, platelet aggregation suppression, factor deficiencies, fibrinolysis and thromboembolic phenomenon.[9] Most cases of coagulation abnormalities are mild and asymptomatic, however, severe cases can lead to major 
complications such as cerebrovascular accidents, limb loss from ischaemia and disseminated intravascular coagulopathy (DIC) which may worsen morbidity; the effects of which may persist even after correction of the heart defects.[10]

Coagulation abnormalities can be assessed using the baseline tests for detecting coagulation abnormalities [Prothrombin time (PT), activated partial thromboplastin time (APTT)] in addition to D-dimer assay which has a $95 \%$ sensitivity for detecting disseminated intravascular coagulation (DIC).[11]

Data is limited concerning the prevalence and significance of CHD coagulation abnormality in developing countries. Studies from developed countries reported a wide prevalence of 19 to $70 \%[12,13]$, thus extrapolating these findings to populations in developing countries might be misleading. This is because the spectrum of routine care and affordability of interventions readily available in developed countries is mostly unavailable in developing countries like Nigeria. Furthermore, coagulopathy in CCHD has been studied more frequently than ACHD, although acyanotic CHD is commonly seen. [14] Therefore, to improve the quality of care offered to this population until definitive corrective intervention is obtained, it is important to identify, monitor and treat any coagulation abnormality to avoid development of irreversible life-limiting end-organ damage. 
medRxiv preprint doi: https://doi.org/10.1101/2022.01.31.22270219; this version posted February 1, 2022. The copyright holder for this preprint (which was not certified by peer review) is the author/funder, who has granted medRxiv a license to display the preprint in perpetuity.

It is made available under a CC-BY 4.0 International license.

Thus, the objective of the study was to determine the prevalence of coagulation abnormality in the paediatric uncorrected congenital heart defect population and to identify the associated risk factors in a cohort of Nigerian children. 


\section{Materials and methods}

It was a cross sectional study conducted at the Lagos University Teaching Hospital (LUTH), Lagos, South west Nigeria from March 2019 to September 2019, after ethical approval was obtained from the Health Research Ethics Committee. The institution is a tertiary hospital that receives referrals from other healthcare facilities in the state and its environs.

Study participants were recruited from the Cardiology clinic, Cardiovascular laboratory and Paediatric outpatient clinics of the hospital using a consecutive sampling method.

\section{Study population}

The presence of congenital heart defect was based on the documentary evidence of echocardiography report. Thereafter, consecutive patients with uncorrected CHDs between 6 months to 17 years of age were included in the study while healthy age and sex matched children, who had no clinical evidence of congenital heart defects were recruited as controls. Written informed consent was obtained from parents or guardians of all study participants with additional informed written assent from children aged seven years and above.

Patients previously diagnosed with chronic renal failure, chronic liver disease, malignancies, HIV infection, sickle cell anaemia were excluded from the study. Children who had been on anti-inflammatory medications such as aspirin in the preceding two weeks, as well those with family history of bleeding disorders such as haemophilia were also excluded. Clinical examination and anthropometry were carried out on CHD subjects and controls and a pre-tested questionnaire (S1 Appendix) was also used to obtain 
biodata, clinical information, and socio-demographic characteristics (age, gender, socioeconomic class which included occupational status and highest level of education attained by each parent and/or guardian using Oyedeji classification of social class). [15] Heart failure was classified using the Modified Ross Heart Failure Classification for Children.

Prothrombin time (PT) and APTT values greater than 2SD of the mean values were reported as prolonged, as recommended by the Clinical \& Laboratory Standard Institute (CLSI) on defining, establishing and verifying reference intervals in the clinical laboratory.[16]

\section{Blood sample collection}

Four milliliters of venous blood was withdrawn aseptically from each participant; two milliliters was added into a marked 3.2\% citrated bottle for the clotting profile analysis (so as to maintain a standard 9:1 blood to anticoagulant ratio), while two milliliters was collected into an ethylene diamine tetra-acetic acid (EDTA) bottle for evaluation of haematocrit and platelet count. For cyanotic patients with known haematocrit levels above $55 \%$, the haematocrit value was first checked and the amount of anticoagulant in the collection tube was adjusted according to the CLSI guidelines.[16]

All blood samples withdrawn were transported in a cooler box $\left(+4\right.$ to $\left.+8{ }^{\circ} \mathrm{C}\right)$ in an upright position on the tube racks to the Central Research Laboratory of the College of Medicine, University of Lagos (CMUL), Lagos. Before receiving the samples at the LUTH Central Research Laboratory, the haematologist independently inspected the collected samples, and removed those samples that were deemed insufficient, with blood clots or evidence 
of haemolysis. Within 4 hours of collection, the samples were centrifuged at $1500 \mathrm{rpm}$ for $15 \mathrm{mins}$, the resultant platelet poor plasma was extracted using pipettes into cryo bottles in three aliquots of $0.5 \mathrm{mls}$ and stored at $\quad-70{ }^{\circ} \mathrm{C}$ at the CMUL Central Research Laboratory for a month to maintain potency until analysis.

\section{Laboratory analysis}

Complete blood count was analysed using a Mindray BC-3200 Automated Haematology Analyzer (Shenzhen, China).

Activated partial thromboplastin time was determined using the coagulometer, a CA-101 (Sysmex, India), a compact semi-automated coagulation analyzer. Fifty microliters of platelet poor plasma $(0.05 \mathrm{mls})$ was pipetted into a cuvette and fifty microliters of APTT reagent, Actin FS (Siemens Healthcare Diagnostics Product GmbH, Marburg, Germany) containing phospholipid and a contact activator, was added and incubated in the coagulometer at $37{ }^{\circ} \mathrm{C}$ for three minutes. Thereafter, $0.05 \mathrm{mls}$ of calcium chloride solution (pre-warmed to $37^{\circ} \mathrm{C}$ ) was added and timing begun. The aPTT is the time taken from the addition of the calcium to the formation of a fibrin clot.

Prothrombin time was also determined using the coagulometer. Fifty microliters of platelet poor plasma $(0.05 \mathrm{mls})$ was pipetted into a cuvette and incubated for 30 seconds. Thereafter, $0.1 \mathrm{ml}$ of PT reagent, Dade Innovin (Siemens Healthcare Diagnostics Product $\mathrm{GmbH}$, Marburg, Germany) a tissue factor containing phospholipid, was added and incubated at $37^{\circ} \mathrm{C}$ and timing begun. 
All tests were done in duplicates, and the average of the two readings was recorded, a difference of not more than 10\% was allowed. A known quality control sample (pooled plasma of known PT and APTT values) was also run to ascertain validity of the test.

D-dimer was assayed by enzyme linked immunosorbent assay (ELISA) using the Human D-dimer ELISA microwells kit (Bioassay Technology Laboratory, China) designed for quantitative detection of d-dimer in human serum or plasma. The kit is a solid phase sandwich assay method, based on a streptavidin-biotin principle.

Coagulation abnormality was defined as thrombocytopaenia, prolonged prothrombin time and/or activated partial thromboplastin time and elevated D-dimer assay levels.

\section{Follow up of study participants}

Laboratory results were made available to study participants. This was done mainly by telephone calls and distributing personal hard copies of the laboratory results to the parents/guardian during their follow up appointments. For the children with abnormal but asymptomatic coagulation tests, results were communicated to their managing physicians, to be co-managed with the Haematology unit of LUTH through short clinic appointments with a recommendation for proactive vigilance for a bleeding diathesis or thrombotic event or both. The caregivers of children with uncorrected CHD were also counseled on the need for prompt surgical correction of the cardiac defects.

\section{Data analysis}

Statistical analysis was performed using Statistical Package for Social Sciences (SPSS) (version 21) Armonk, NY:IBM Corp. 
Quantitative data was tested for normality using Shapiro-Wilk test. Normally distributed data was summarized using mean and standard deviation, while skewed data was presented as median and interquartile range. Conversely, categorical variables (demographic, anthropometry and laboratory findings) were summarized using frequencies and proportions. Comparison of the prevalence of coagulation abnormalities between the subject group and control group was done using the Chi square test. Comparison of normally distributed continuous data (laboratory findings) between the cyanotic and acyanotic groups was tested using student $t$ test while similar comparison between skewed data were made using Mann Whitney U test. Comparison of categorical variables between cyanotic and acyanotic groups was done using the Chi-square test. Variables that were statistically significantly associated with coagulation abnormalities were subjected to further statistical test using multiple logistic regression to determine the independent predictors of coagulation abnormalities. For all statistical analyses, $p$ value less than 0.05 was considered statistically significant. 


\section{Results}

A total of 144 children were recruited for the study. Four of them were excluded from data analysis on account of inability to run the laboratory tests due to clotted samples.

\section{Characteristics of CHD subjects and the controls}

A total of one hundred and forty children were enrolled in the study: seventy children each in the uncorrected congenital heart defects and apparently healthy aged and sex matched control groups.

Table 1 shows a summary of the demography and anthropometric findings in CHD subjects and controls. The study population ages ranged from 6 months to 15 years with majority in the 1-5 years group. The median (IQR) age of the two groups was comparable 36.0 (18.0-84.0) months in the CHD and 48.0 (20.0-87.0) months in the healthy control $(p$-value $=0.985)$. The male-female proportion was $42.9 \%$ and $57.1 \%$. Most of the caregivers of the study population were in the middle socioeconomic class. The median weight, height and body mass index were lower for CHD subjects compared to controls. Children with CHD were significantly stunted and wasted compared to the healthy controls. Twenty-nine (41.4\%) and $26(37.2 \%)$ of the children with uncorrected CHDs were wasted and stunted respectively. compared to $11(15.7 \%)$ and $10(14.3 \%)$ of the healthy controls who were wasted and stunted, $p=<0.001$

Table I: Socio-demographic and anthropometry of study population

\begin{tabular}{|l|c|c|l|l|}
\hline \multirow{2}{*}{$\begin{array}{l}\text { Variable } \\
\text { (\%) }\end{array}$} & Congenital heart defects & Controls & $\begin{array}{l}\text { Test } \\
\text { statistic }\end{array}$ & \multirow{p}{*}{$\boldsymbol{p}$-value } \\
\cline { 1 - 4 } & $\mathbf{n = 7 0}$ & $\mathbf{n = 7 0}$ & $\chi^{2}$ & \\
\hline Age, median (IQR), months & $36.0(18.0-84.0)$ & $48.0(20.0-87.0)$ & & 0.985 \\
\hline Age group & & & & \\
\hline \multicolumn{1}{|c|}{6 months -1 year } & $8(11.4)$ & $8(11.4)$ & & \\
\hline
\end{tabular}


medRxiv preprint doi: https://doi.org/10.1101/2022.01.31.22270219; this version posted February 1, 2022. The copyright holder for this preprint (which was not certified by peer review) is the author/funder, who has granted medRxiv a license to display the preprint in perpetuity.

It is made available under a CC-BY 4.0 International license .

\begin{tabular}{|c|c|c|c|c|}
\hline 1 to $<5$ years & $34(48.6)$ & $34(48.6)$ & $\chi^{2}=0.000$ & 1.000 \\
\hline 5 to $<10$ years & $19(27.1)$ & $19(27.1)$ & & \\
\hline$\geq 10$ years & $9(12.9)$ & $9(12.9)$ & & \\
\hline \multicolumn{5}{|l|}{ Sex } \\
\hline Females & $40(57.1)$ & $40(57.1)$ & $\chi^{2}=0.116$ & 1.000 \\
\hline Males & $30(42.9)$ & $30(42.9)$ & & \\
\hline \multicolumn{5}{|l|}{ Socioeconomic class } \\
\hline Low & $11(15.7)$ & $4(5.7)$ & & \\
\hline Middle & $35(50.0)$ & $29(41.4)$ & $\chi^{2}=6.600$ & 0.037 \\
\hline High & $24(34.3)$ & $37(52.9)$ & & \\
\hline \multicolumn{5}{|l|}{ Anthropometry } \\
\hline BMI for age, median (IQR) & $-1.6(-2.7$ to -0.7$)$ & $-0.4(-1.0$ to -0.9$)$ & $\mathrm{F}=35.169$ & $<0.001^{\#}$ \\
\hline Height for age, median (IQR) & $-1.4(-2.4$ to -0.5$)$ & $0(-1.3$ to 0.8$)$ & $\mathrm{F}=24.669$ & $<0.001^{\#}$ \\
\hline Weight for age, median (IQR) & $-2.0(-3.0$ to -1.3$)$ & $-0.4(-0.9$ to 0.4$)$ & $\mathrm{F}=60.682$ & $<0.001^{\#}$ \\
\hline \multicolumn{5}{|l|}{ BMI for age, $n(\%)$} \\
\hline Normal & $41(58.6)$ & $52(74.3)$ & $\mathrm{F}=23.612$ & $<0.001$ \\
\hline Wasted & $13(18.5)$ & $10(14.3)$ & & \\
\hline Severely wasted & $16(22.9)$ & $1(1.4)$ & & \\
\hline Overweight & $0(0)$ & $7(10)$ & & \\
\hline \multicolumn{5}{|l|}{ Height for age, $n(\%)$} \\
\hline Normal & $44(62.8)$ & $55(78.6)$ & $\mathrm{F}=17.845$ & $<0.001$ \\
\hline Stunted & $13(18.6)$ & $9(12.9)$ & & \\
\hline Severely stunted & $13(18.6)$ & $1(1.4)$ & & \\
\hline Tall & $0(0)$ & $5(7.1)$ & & \\
\hline
\end{tabular}

$\chi^{2}$ : Chi-square. $\mathrm{F}=$ Fischer's test

${ }^{\#} p$ value statistically significant

\section{Characteristics of children with CHD}

For children with acyanotic congenital heart defects: Isolated VSD 14 (40\%), Isolated ASD 6 (17.1\%) and Isolated PDA 3 (8.5\%) were the most common types, while Tetralogy of Fallot $20(57.1 \%)$ and Truncus arteriosus 4 (11.4\%) were the commonest CCHD. Heart failure was diagnosed in 32 of the $70 \mathrm{CHD}$ children, of which $87.5 \%$ of them had ACHD (Modified Ross Heart failure classification) as shown in Table 2. 
Table 2: Distribution of Congenital heart defects.

\begin{tabular}{|c|c|}
\hline Characteristics of CHD & n (\%) \\
\hline \multicolumn{2}{|l|}{ Acyanotic CHD } \\
\hline Isolated VSD & $14(40)$ \\
\hline Isolated PDA & $3(8.5)$ \\
\hline Isolated ASD & $6(17.1)$ \\
\hline $\mathrm{VSD}+\mathrm{PDA}$ & $1(2.9)$ \\
\hline $\mathrm{VSD}+\mathrm{PS}$ & $1(2.9)$ \\
\hline AVSD & $4(11.4)$ \\
\hline $\mathrm{VSD}+\mathrm{ASD}$ & $3(8.5)$ \\
\hline $\mathrm{ASD}+\mathrm{PS}$ & $1(2.9)$ \\
\hline Bicuspid aortic valve & $1(2.9)$ \\
\hline Coarctation of the aorta & $1(2.9)$ \\
\hline Total & $35(50)$ \\
\hline \multicolumn{2}{|l|}{ Cyanotic CHD } \\
\hline TOF & $20(57.1)$ \\
\hline DORV & $2(5.7)$ \\
\hline DILV & $1(2.9)$ \\
\hline Truncus arteriosus & $4(11.4)$ \\
\hline PA & $2(5.7)$ \\
\hline Tricuspid atresia & $2(5.7)$ \\
\hline Ebstein anomaly & $1(2.9)$ \\
\hline TGA & $2(5.7)$ \\
\hline HLHS & $1(2.9)$ \\
\hline Total & $35(50)$ \\
\hline \multicolumn{2}{|l|}{ Heart failure Present } \\
\hline ACHD (35) & 28 \\
\hline CCHD (35) & 4 \\
\hline
\end{tabular}

*VSD: ventricular septal defect; PDA: patent ductus arteriosus; ASD: atrial septal defect; PS: pulmonary stenosis; AVSD: atrioventricular septal defect; TOF: tetralogy of Fallot; DORV: double outlet right ventricle; DILV: double inlet left ventricle TA: Truncus arteriosus; PA: pulmonary atresia, TGA: Transposition of Great arteries, HLHS: hypoplastic left heart syndrome. 
medRxiv preprint doi: https://doi.org/10.1101/2022.01.31.22270219; this version posted February 1, 2022. The copyright holder for this preprint (which was not certified by peer review) is the author/funder, who has granted medRxiv a license to display the preprint in perpetuity.

It is made available under a CC-BY 4.0 International license .

\section{Prevalence of Coagulation abnormalities in children with CHD and Controls}

The proportion of uncorrected CHD cohort with coagulation abnormality, defined as

thrombocytopaenia, prolonged prothrombin time and/or activated partial thromboplastin

time and elevated D-dimer assay was 26 (37.1\%), which was much higher than $5(7.1 \%)$

in apparently healthy controls as shown in Fig 1.

\section{Comparison of Coagulation profile in children with CHD and Controls}

Table 3 shows the mean values of coagulation parameters in CHD subjects and controls.

Children with CHD had prolonged APTT and PT $(44.4 \pm 10.7$ and $14.7 \pm 3.5$

respectively) compared with controls $(39.7 \pm 7.3$ and $12.9 \pm 1.7)$ (p-value $<0.05)$. The

median platelet count of the children with congenital heart defects was much lower than

the median of the controls. However, there was no significant difference in the D-dimer

levels between children with CHD and controls.

Table 3: Comparison of coagulation profile between CHD subjects and controls

\begin{tabular}{|l|c|c|c|c|}
\hline Variables & $\begin{array}{c}\text { Congenital heart } \\
\text { defects }\end{array}$ & Controls & $\begin{array}{c}\text { Test } \\
\text { statistics }\end{array}$ & $\begin{array}{c}\mathrm{P} \\
\text { value }\end{array}$ \\
\hline $\begin{array}{l}\text { Median (IQR) platelet count } \\
\left(\mathrm{x} 10^{9} \text { cells/mm }\right)^{3}\end{array}$ & $\begin{array}{c}240.1(163.0- \\
326.0)\end{array}$ & $\begin{array}{c}356.0(275.0- \\
679.0)\end{array}$ & $\mathrm{U}$ & 0.000 \\
\hline $\begin{array}{l}\text { Prothrombin time, } \\
\text { mean } \pm S D \text {, seconds }\end{array}$ & $14.7 \pm 3.5$ & $12.9 \pm 1.7$ & $\mathrm{t}$ & $<0.001$ \\
\hline $\begin{array}{l}\text { International Normalized Ratio } \\
\text { mean } \pm S D\end{array}$ & $1.1 \pm 0.3$ & $0.9 \pm 0.1$ & $\mathrm{t}$ & $<0.001$ \\
\hline $\begin{array}{l}\text { Activated partial thromboplastin time, } \\
\text { mean } \pm S D, \text { seconds }\end{array}$ & $44.4 \pm 10.7$ & $39.7 \pm 7.3$ & $\mathrm{t}$ & 0.003 \\
\hline Median (IQR) D-dimer (pg/ml) & $1.0(0.8-1.5)$ & $1.2(0.8-2.1)$ & $\mathrm{U}$ & 0.092 \\
\hline
\end{tabular}

U: Mann Whitney U test t: Student's t-test 
medRxiv preprint doi: https://doi.org/10.1101/2022.01.31.22270219; this version posted February 1, 2022. The copyright holder for this preprint (which was not certified by peer review) is the author/funder, who has granted medRxiv a license to display the preprint in perpetuity.

It is made available under a CC-BY 4.0 International license.

\section{Prevalence of Coagulation abnormalities in children with Acyanotic and Cyanotic Congenital heart defects.}

Coagulation abnormalities were more common in the cyanotic CHD group compared to the acyanotic group $[20(57.1 \%)$ versus $6(17.1 \%)]$ with a $p$ value of 0.001 . The proportion of coagulation abnormality in the two subgroups is as shown in Table 4

Table 4: Coagulation abnormalities in children with ACHD and CCHD

\begin{tabular}{|l|c|c|c|c|}
\hline $\begin{array}{l}\text { Variable } \\
\text { N (\%) }\end{array}$ & $\begin{array}{c}\text { ACHD } \\
\mathbf{n = 3 5}\end{array}$ & $\begin{array}{c}\mathbf{C C H D} \\
\mathbf{n = 3 5}\end{array}$ & $\begin{array}{c}\text { Test statistic } \\
\chi^{2}\end{array}$ & p-value \\
\hline Coagulation abnormality & $6(17.1)$ & $20(57.1)$ & 11.933 & 0.001 \\
\hline Thrombocytopaenia & $0(0.0)$ & $8(22.9)$ & 9.032 & 0.002 \\
\hline Prolonged PT/INR & $2(5.7)$ & $11(31.4)$ & 7.652 & 0.006 \\
\hline Prolonged APTT & $2(5.7)$ & $9(25.7)$ & 5.285 & 0.023 \\
\hline Elevated D-dimer $(\mathrm{pg} / \mathrm{ml})$ & $3(8.6)$ & $3(8.6)$ & 0.000 & 0.663 \\
\hline
\end{tabular}

$\chi^{2}$ : Chi-square.

Six children with ACHD had coagulation abnormalities: 5 had abnormal results in only one test while 1 had in two tests.

Twenty children with CCHD had coagulation abnormalities: 12 had abnormal results in one test while 8 had in two or more tests.

\section{Factors associated with coagulation abnormalities in children with CHD}

There was no significant association between the socio-demographic characteristics (age, sex, and socioeconomic class), nutritional status (height for age, BMI) and the prevalence of coagulation abnormality in children with congenital heart defects. Coagulation abnormality was more in CHD subjects that were less than 5 years of age, though it was not statistically significant. CHD subjects with coagulation abnormality had higher mean values of haematocrit and lower mean values of oxygen saturation levels as shown in Table 5 . 
Table 5: Association between socio demographic characteristics, nutritional status and the prevalence of coagulation abnormality in children with CHD.

\begin{tabular}{|l|c|c|c|c|}
\hline Variables (n=70) & \multicolumn{2}{|c|}{ Coagulation abnormality } & $\begin{array}{c}\text { Test } \\
\text { statistics }\end{array}$ & P-value \\
\hline & $Y e s(n=26)$ & No $(n=44)$ & & \\
\hline Age group & & & & \\
\hline 6 months to $<1$ year & $3(11.5)$ & $5(11.4)$ & & \\
\hline 1 year to $<5$ years & $13(50.0)$ & $21(47.7)$ & $\chi^{2}=1.076$ & 0.783 \\
\hline 5 years to $<10$ years & $8(30.8)$ & $11(25.0)$ & & \\
\hline$\geq 10$ years & $2(7.7)$ & $7(15.9)$ & & \\
\hline Sex & & & & \\
\hline Male & $11(42.3)$ & $19(43.2)$ & $\chi^{2}=0.193$ & 0.660 \\
\hline Female & $15(57.7)$ & $25(56.8)$ & & \\
\hline Height for age & & & & \\
\hline Normal & $16(61.6)$ & $28(63.6)$ & & 0.985 \\
\hline Stunted & $5(19.2)$ & $8(18.2)$ & $\chi^{2}=0.031$ & \\
\hline Severely stunted & $5(19.2)$ & $8(18.2)$ & & \\
\hline BMI for age & & & & \\
\hline Normal & $13(50.0)$ & $28(63.6)$ & $\chi^{2}=1.661$ & \\
\hline Wasted & $5(19.2)$ & $8(18.2)$ & & 0.436 \\
\hline Heart failure class & & & & \\
\hline None & $13(50.0)$ & $25(56.8)$ & & \\
\hline Class I & $8(30.8)$ & $18(40.9)$ & & 0.051 \\
\hline Class II & $5(19.2)$ & $0(0.0)$ & & \\
\hline Class III & $0(0.0)$ & $1(2.3)$ & & \\
\hline Oxygen saturation in room air \\
(mean \pm SD)
\end{tabular}

$\chi^{2}$ : Chi-square. $\mathrm{t}=$ Student $\mathrm{t}$-test

Table 6 showed that socio-demographic characteristics (age, sex) and anthropometry were not independent predictors of coagulation abnormalities. Coagulation abnormality was 6 times [6.444 (2.135-19.456)] more likely to occur in children with CCHD compared with children with ACHD. 
Table 6: Independent variables associated with coagulation abnormality

\begin{tabular}{|c|c|c|c|c|}
\hline \multirow[t]{2}{*}{ Variable } & \multirow[t]{2}{*}{ Adjusted odds ratio } & \multirow[t]{2}{*}{$P$ value } & \multicolumn{2}{|c|}{$95 \% \mathrm{CI}$} \\
\hline & & & Lower bound & Upper bound \\
\hline & & \multicolumn{3}{|c|}{ Coagulation profile } \\
\hline Age group & & & & \\
\hline 6 months -1 year (vs. $\geq 10$ years) & 2.100 & 0.494 & 0.251 & 17.594 \\
\hline 1 to $<5$ years (vs. $\geq 10$ years) & 2.167 & 0.377 & 0.389 & 12.063 \\
\hline 5 to $<10$ years (vs. $\geq 10$ years) & 2.545 & 0.313 & 0.414 & 15.652 \\
\hline Sex & & & & \\
\hline $\begin{array}{l}\text { Male vs. Female } \\
\text { Cardiac defects } \\
\text { Cyanotic CHD vs Acyanotic }\end{array}$ & $\begin{array}{l}1.254 \\
6.444\end{array}$ & $\begin{array}{l}0.660 \\
0.001\end{array}$ & $\begin{array}{l}0.469 \\
2.135\end{array}$ & 3.309 \\
\hline Height for age & & & & \\
\hline Normal (vs. severely stunted) & 1.000 & 1.0000 & 0.206 & 4.856 \\
\hline Stunted (vs. severely stunted) & 0.914 & 0.890 & 0.255 & 3.272 \\
\hline BMI for age & & & & \\
\hline Normal (vs. severely wasted) & 0.464 & 0.203 & 0.143 & 1.511 \\
\hline Wasted (vs. severely wasted) & 0.625 & 0.535 & 0.141 & 2.763 \\
\hline
\end{tabular}

Table 7 showed that haematocrit level and oxygen saturation had a statistically significant association on levels of platelet count, prothrombin time and INR. The model shows that haematocrit value and oxygen saturation have stronger effects on the platelet count and prothrombin time/INR. 
Table 7: Multivariate logistic analysis of significant variables and Coagulation abnormality

\begin{tabular}{|c|c|c|c|c|c|c|}
\hline \multirow[t]{2}{*}{ Variable $^{\mathrm{a}}$} & \multirow[t]{2}{*}{$\mathbf{B}$} & \multirow{2}{*}{$\begin{array}{c}\text { Standardized } \\
\text { Beta- } \\
\text { coefficient }\end{array}$} & \multirow[t]{2}{*}{ SE } & \multirow[t]{2}{*}{ p-value } & \multicolumn{2}{|c|}{$95 \% \mathrm{CI}$} \\
\hline & & & & & $\begin{array}{l}\text { Lower } \\
\text { bound }\end{array}$ & $\begin{array}{l}\text { Upper } \\
\text { bound }\end{array}$ \\
\hline & & \multicolumn{5}{|c|}{ Platelet count (cell/mm3) } \\
\hline Haematocrit (\%) & -5073.1 & -0.408 & 1391.0 & 0.001 & -7850.4 & -2295.8 \\
\hline \multirow[t]{2}{*}{ Oxygen saturation } & 5886.7 & 0.438 & 1477.1 & 0.000 & 2935.8 & 8837.6 \\
\hline & & \multicolumn{5}{|c|}{ Prothrombin time (secs) } \\
\hline Haematocrit (\%) & 0.117 & 0.426 & 0.030 & 0.000 & .057 & .177 \\
\hline \multirow[t]{2}{*}{ Oxygen saturation } & -0.085 & -0.286 & 0.034 & 0.016 & -0.153 & -0.016 \\
\hline & & \multicolumn{5}{|c|}{ International normalised ratio } \\
\hline Haematocrit (\%) & 0.011 & 0.480 & 0.002 & 0.000 & 0.006 & 0.015 \\
\hline \multirow[t]{2}{*}{ Oxygen saturation } & -0.007 & -0.300 & 0.003 & 0.011 & -0.013 & -0.002 \\
\hline & & \multicolumn{5}{|c|}{ aPTT } \\
\hline Haematocrit (\%) & 0.152 & 0.180 & 0.102 & 0.142 & -0.052 & 0.355 \\
\hline \multirow[t]{2}{*}{ Oxygen saturation } & 0.004 & 0.005 & 0.112 & 0.969 & -0.219 & 0.228 \\
\hline & & \multicolumn{5}{|c|}{ D-Dimer (pg/ml) } \\
\hline Haematocrit (\%) & -0.005 & -0.076 & 0.008 & 0.527 & -0.021 & 0.011 \\
\hline Oxygen saturation & 0.000 & -0.004 & 0.009 & 0.975 & -0.018 & 0.017 \\
\hline
\end{tabular}

a Adjusted for socioeconomic class and nutritional status

Pearson's correlation was carried out to demonstrate relationship between coagulation abnormality and factors such as age, anthropometry, oxygen saturation and haematocrit. Table 8 shows that haematocrit value and oxygen saturation had stronger effects on the platelet count and prothrombin time/INR. There was moderate negative correlation between haematocrit and platelet count $(\mathrm{r}=-0.414, \mathrm{p}=0.000)$ and a moderate positive 
correlation between the haematocrit level of children with CHD and prothrombin time/

INR $(r=+0.416, p=0.000)$. There was also a positive moderate correlation between the oxygen saturation level of children with CHD and platelet count $(r=+0.443, p=0.000)$. There was no correlation between age of patient, anthropometry and coagulation abnormality.

Table 8: Correlation between coagulation parameters and some independent factors

\begin{tabular}{|l|c|c|c|c|c|}
\hline Variables (n=70) & Platelet & Prothrombin & Partial & International & D-dimer \\
& count & time & thromboplastin & Normalised & \\
& & & time & ratio & \\
\hline Age & $\mathrm{r}=-0.215$ & $\mathrm{r}=0.099$ & $\mathrm{r}=-0.068$ & $\mathrm{r}=0.199$ & $\mathrm{r}=-0.324$ \\
& $\mathrm{p}=0.074$ & $\mathrm{p}=0.415$ & $\mathrm{p}=0.577$ & $\mathrm{p}=0.099$ & $\mathrm{p}=0.006$ \\
\hline Weight for age & $\mathrm{r}=-0.122$ & $\mathrm{r}=-0.143$ & $\mathrm{r}=-0.015$ & $\mathrm{r}=-0.146$ & $\mathrm{r}=-0.031$ \\
& $\mathrm{p}=0.340$ & $\mathrm{p}=0.264$ & $\mathrm{p}=0.908$ & $\mathrm{p}=0.254$ & $\mathrm{p}=0.811$ \\
\hline Height for age & $\mathrm{r}=-0.063$ & $\mathrm{r}=-0.076$ & $\mathrm{r}=-0.041$ & $\mathrm{r}=-0.087$ & $\mathrm{r}=-0.084$ \\
& $\mathrm{p}=0.604$ & $\mathrm{p}=0.531$ & $\mathrm{p}=0.735$ & $\mathrm{p}=0.473$ & $\mathrm{p}=0.489$ \\
\hline BMI for age & $\mathrm{r}=-0.104$ & $\mathrm{r}=-0.202$ & $\mathrm{r}=0.044$ & $\mathrm{r}=-0.199$ & $\mathrm{r}=0.000$ \\
& $\mathrm{p}=0.392$ & $\mathrm{p}=0.093$ & $\mathrm{p}=0.718$ & $\mathrm{p}=0.098$ & $\mathrm{p}=1.000$ \\
\hline Oxygen saturation & $\mathrm{r}=0.443$ & $\mathrm{r}=-0.285$ & $\mathrm{r}=0.000$ & $\mathrm{r}=-0.298$ & $\mathrm{r}=-0.024$ \\
& $\mathrm{p}=0.000$ & $\mathrm{p}=0.017$ & $\mathrm{p}=0.997$ & $\mathrm{p}=0.012$ & $\mathrm{p}=0.841$ \\
\hline Haematocrit level & $\mathrm{r}=-0.414$ & $\mathrm{r}=0.416$ & $\mathrm{r}=0.187$ & $\mathrm{r}=0.471$ & $\mathrm{r}=-0.066$ \\
& $\mathrm{p}=0.000$ & $\mathrm{p}=0.000$ & $\mathrm{p}=0.122$ & $\mathrm{p}=0.000$ & $\mathrm{p}=0.586$ \\
\hline
\end{tabular}




\section{Discussion}

This study determined the prevalence of coagulation abnormalities (thrombocytopaenia, prolonged clotting profile and elevated d-dimer levels) in children with uncorrected congenital heart defects and reported a prevalence of $37.1 \%$, compared to $7.2 \%$ in the healthy cohort. The mean clotting profile of children with uncorrected CHD was significantly prolonged and comparable to an earlier report by Cheung.[17] These findings in our study can be attributed to the uncorrected congenital heart defect, which has been reported to cause a chronic consumption coagulopathy.

Our prevalence was higher than that reported by Colon et al in the United States among a mixed cohort of adults and children, some of whom had corrected heart defects.[13] This is possibly due to the cohort of children with uncorrected CHDs in the current study, which reflects the pool of children with CHD in sub-Saharan Africa where cardiac intervention is delayed due to high cost of surgery and inadequate manpower. In comparison, our prevalence was lower than reports from the Indian sub-continent, which were in small patient populations. $[12,18]$ These investigators proposed that their cohort had severe cardiac defects. Nevertheless, the relatively high prevalence of coagulation abnormality between CHD cohort in this current study compared to the healthy population further highlights that chronic disseminated intravascular coagulopathy occur in children with CHD. The prevalence among the apparently healthy population in this current study was comparable to the report by Alzahrani et al [19] in Saudi Arabia. It was however lower than figures reported by Acosta et al [20] in the US and Onakoya [21] in 
South West Nigeria respectively. The low rates in the current study might be linked to the exclusion of children with bleeding disorders as well as the study design utilized. It may then be assumed that coagulation disorders occur even among apparently healthy children. Viral infections have been implicated in the prevalence of coagulation defects in apparently healthy cohorts. This is due to the elaboration of cytokines that alter the balance between pro and anti-coagulation factors. Thus, pre surgical coagulation screening for all children should be advocated regardless of absence of a family history of bleeding disorders.

The prevalence of coagulation abnormalities in children with CCHD was significantly higher than the ACHD cohort, which is similar to earlier published reports. [13] In our population of children with CHD, slightly less than a quarter of the CCHD arm had thrombocytopenia with no thrombocytopenia reported among the ACHD arm. This is similar to a report in the US among a cohort of children with CCHD.[22] This was also corroborated by a study from Europe.[13] Decreased platelet counts may be due to the increased platelet destruction, aggregation and activation as well as reduced platelet production due to the right to left shunts, which deliver megakaryocytes into the systemic arterial circulation bypassing the lungs where megakaryocytic cytoplasm is fragmented into platelets.[23.24]

Similar to earlier reports, PT and aPTT were the most deranged coagulation screening tests in this study.[12,13] Prolonged PT/INR and APTT were significantly higher in children with CCHD compared to the ACHD cohort. A high prevalence $(35.5 \%$ and $37.5 \%$ ) of prolonged PT/INR in CCHD has also been reported among children with 
CCHD in East Africa. [25,26]. However, in a report from the United States, a higher rate was noted among children aged 3 to 19 months with CCHD. [27]. This was probably due to the predominance of infants in their study group, which may have partly accounted for the higher rates, as infants are known to have physiologic maturational delay in haemostasis.[28]

Elevated D-dimer level was seen equally in both ACHD and CCHD groups in the current study. A study in Nairobi however reported a significantly higher rate in the CCHD cohort.[26] Children with CCHD are at a higher risk of chronic thrombus formation due to hypoxic induced polycythaemia while, the chronic heart failure in ACHD causes cardiac dilatation, leading to reduced blood perfusion and possibly blood stasis with consequent tendency to thrombus formation.

Coagulation abnormalities were found to be highest in under fives, compared to the older age group. The difference was however not statistically significant. This finding is similar to the US study [27], who also found more coagulation abnormalities in participants less than 5 years. This suggests that this complication occur at an early age. Furthermore in the current study, there was no statistically significant relationship between coagulation abnormality and nutritional status.

Similar to published works, $[12,13,17]$ our study showed a weak and negative correlation between oxygen saturation level and coagulation abnormalities. This relationship suggests that hypoxia contributes significantly to the initiation and sustenance of coagulation abnormalities as it leads to endothelial injury, and exposure of the sub- 
endothelial space to blood platelets, with subsequent activation of the coagulation cascade.[31] Hypoxia also results in hepatic hypo-perfusion and reduced production of clotting factors.

Furthermore, the correlation between haematocrit level, thrombocytopaenia and prolonged prothrombin time though weak, was statistically significant and in concordance with previous studies in Japan and United States of America. [22,32] This affirms the role of polycythaemia and platelet dysfunction in the promotion of abnormal coagulation cascade in uncorrected congenital heart defects. Elevated haemoglobin results in hyper-viscosity with resultant increased endothelial dysfunction, platelet activation and subsequently accelerated activation of the clotting cascade.

The limitation in the present study was inability to use point of care testing for coagulation analysis, which is a more sensitive diagnostic test for coagulation analysis as it uses whole blood sample and better represent actual clotting function.

\section{Conclusion}

It is evident that coagulation abnormalities are more prevalent among children with uncorrected cyanotic CHD when compared to those with acyanotic and apparently normal children. Oxygen saturation and haematocrit are factors associated with these abnormalities. There is thus a need for periodic evaluation for coagulation abnormalities in children with congenital heart defects to improve their quality of life and disease burden while they await corrective surgeries.

We recommend early and twice yearly regular screening for coagulation abnormalities as part of routine management of children with CHD. 


\section{Acknowledgements}

My sincere gratitude goes to all the children and the parents who participated in this study.

\section{References}

1. Bouma BJ, Mulder BJ. Changing landscape of congenital heart disease. Circ Res 2017;120:908-22.

2. Van der Linde D, Konings EEM, Slager MA, Witsenburg M, Helbing WA, Takkenberg JJM, et al. Birth Prevalence of Congenital Heart Disease Worldwide. J Am Coll Cardiol. 2011;58(21):2241-7.

3. Liu Y, Chen S, Zuhlke L, Black GC, Choy M, Li N et al. Global birth prevalence of congenital heart defects 1970-2017: updated systematic review and metaanalysis of 260 studies. Int J Epidemiol 2019;48:455-63.

4. Ibadin M, Sadoh W, Osarogiagbon W. Congenital heart diseases at the University of Benin Teaching Hospital. Niger J Paediatr. 2005;32(2):29-32.

5. Sani MU, Mukhtar-Yola M, Karaye KM. Spectrum of congenital heart disease in a tropical environment: an echocardiography study. J Natl Med Assoc. 2007;99(6):665-9.

6. Deanfield J, Thaulow E, Warnes C, Webb G, Kolbel F, Hoffman A, et al. Management of grown up congenital heart disease. Eur Heart J. 2003;24(11):1035-84.

7. Ekure E, Bode-Thomas, F, Sadoh W, Orogade AA, Otaigbe BE UF et al. Congenital heart defects in Nigerian Children: Preliminary Data from the National Pediatric Cardiac Registry. World J Pediatr Congenit Hear Surg. 2017;8(6):699_ 
706.

8. Brickner ME, Hillis LD, Lange RA. Congenital Heart Disease in Adults. N Engl J

Med. 2000;342(4):256-63.

9. Ghasemi A, Horri M, Salahshour Y. Coagulation Abnormalities in Pediatric

Patients with Congenital Heart Disease. Int J Pediatr. 2014;2(5):2-2.

10. Sinclair AJ, Fox CK, Ichord RN, Almond CS, Bernard TJ, Beslow LA, et al.

Stroke in children with cardiac disease: report from the International Pediatric

Stroke Study Group Symposium. Pediatr Neurol. 2015;52(1):5-15.

11. Giglia TM, Massicotte MP, Tweddell JS, Barst RJ, Bauman M, Erickson CC, et al. Prevention and treatment of thrombosis in pediatric and congenital heart disease a scientific statement from the american heart association. Circulation. 2013;128(24):2622-703.

12. Arslan M, Ozcetin M, Ozyurek R, Kavakli K. Rate Of Abnormal Coagulation Test Results in Patients with Congenital Heart Disease. J Contemp Med. 2011;1(1):610.

13. Colon-Otero G, Gilchrist GS, Holcomb GR, Ilstrup DM, Bowie EJW. Preoperative evaluation of hemostasis in patients with congenital heart disease. Mayo Clin Proc. 1987;62(5):379-85.

14. Hoffman JIE, Kaplan S, Liberthson RR. Prevalence of congenital heart disease. Vol. 147, American Heart Journal. 2004. p. 425-39.

15. Oyedeji G. Socio-economic and cultural background of hospitalized children in Ilesha. Niger J Paediatr. 1985;12(4):111-7.

16. Castellone DD. Establishing reference intervals in the coagulation laboratory. Int J 
Lab Hematol. 2017;39:121-7.

17. Cheung EWY, Chay GW, Ma ESK, Cheung YF. Systemic oxygen saturation and coagulation factor abnormalities before and after the fontan procedure. Am J Cardiol. 2005;96(11):1571-5.

18. Goel M, Shome DK, Singh ZN, Bhattacharjee J, Khalil A. Haemostatic changes in children with cyanotic and acyanotic congenital heart disease. Indian Heart J. 2000;52(5):559-63.

19 Alzahrani A, Othman N, Bin-Ali T, Elfaraidi H, Al Mussaed E, Alabbas F, et al. Routine Preoperative Coagulation Tests in Children Undergoing Elective Surgery or Invasive Procedures: Are They Still Necessary? Clin Med insights Blood Disord. 2019;12:1179545X18821158.

20. Acosta M, Edwards R, Jaffe ; E Ian, Yee DL, Mahoney DH, Teruya J. Pediatric Patients With Coagulopathy.2 129, Arch Pathol Lab Med. 2005.

21. Onakoya P, Nwaorgu O, Abja U, Kokong D. Adenoidectomy and tonsillectomy: is clotting profile relevant? Niger J Surg Res. 2010:27;6(1-2).

22. Lill MC, Perloff JK, Child JS. Pathogenesis of Thrombocytopenia in Cyanotic Congenital Heart Disease. Am J Cardiol. 2006;98(2):254-8.

23. Zabala LM, Guzzetta NA. Cyanotic congenital heart disease (CCHD): focus on hypoxemia, secondary erythrocytosis, and coagulation alterations. Hammer G, editor. Pediatr Anesth. 2015;25(10):981-9.

24. Ismail EAR, Youssef OI. Platelet-derived microparticles and platelet function profile in children with congenital heart disease. Clin Appl Thromb Hemost. 2013;19(4):424-32. 
25. Samia H. Osman AEA. Hematologic complication of Cyanotic Congenital heart disease: Profile of Unoperated Sudanese Children. Congenit Cardiol Today. 2012;10(10):1.

26. Lang'O M. Haematological manifestations in Cyanotic heart diseases at Kenyatta National Hospital and Mater Hospital, Nairobi. M.Sc. Thesis, University of Nairobi 2008. Available from: http://hdl.handle.net/11295/64357

27. Odegard KC, Zurakowski D, Hornykewycz S, DiNardo JA, Castro RA, Neufeld EJ, et al. Evaluation of the Coagulation System in Children with Two-Ventricle Congenital Heart Disease. 2007;83:1797-804.

28. Developmental Hemostasis: Pro- and Anticoagulant Systems during Childhood. Semin Thromb Hemost. 2003;29(4):329-38.

29. Alvarez AM, Mukherjee D. Liver abnormalities in cardiac diseases and heart failure. Int J Angiol. 2011;20(3):135-42.

30. Asrani SK, Asrani NS, Freese DK, Phillips SD, Warnes CA, Heimbach J, et al. Congenital heart disease and the liver. Hepatology. 2012;56(3):1160-9.

31. Tempe DK, Virmani S. Coagulation abnormalities in patients with cyanotic congenital heart disease. Journal of Cardiothoracic and Vascular Anesthesia. 2002 p. $752-65$.

32. Horigome H, Hiramatsu Y, Shigeta O, Nagasawa T, Matsui A. Overproduction of platelet microparticles in cyanotic congenital heart disease with polycythemia. $\mathbf{J}$ Am Coll Cardiol. 2002;39(6):1072-7. 


\section{RESULTS}

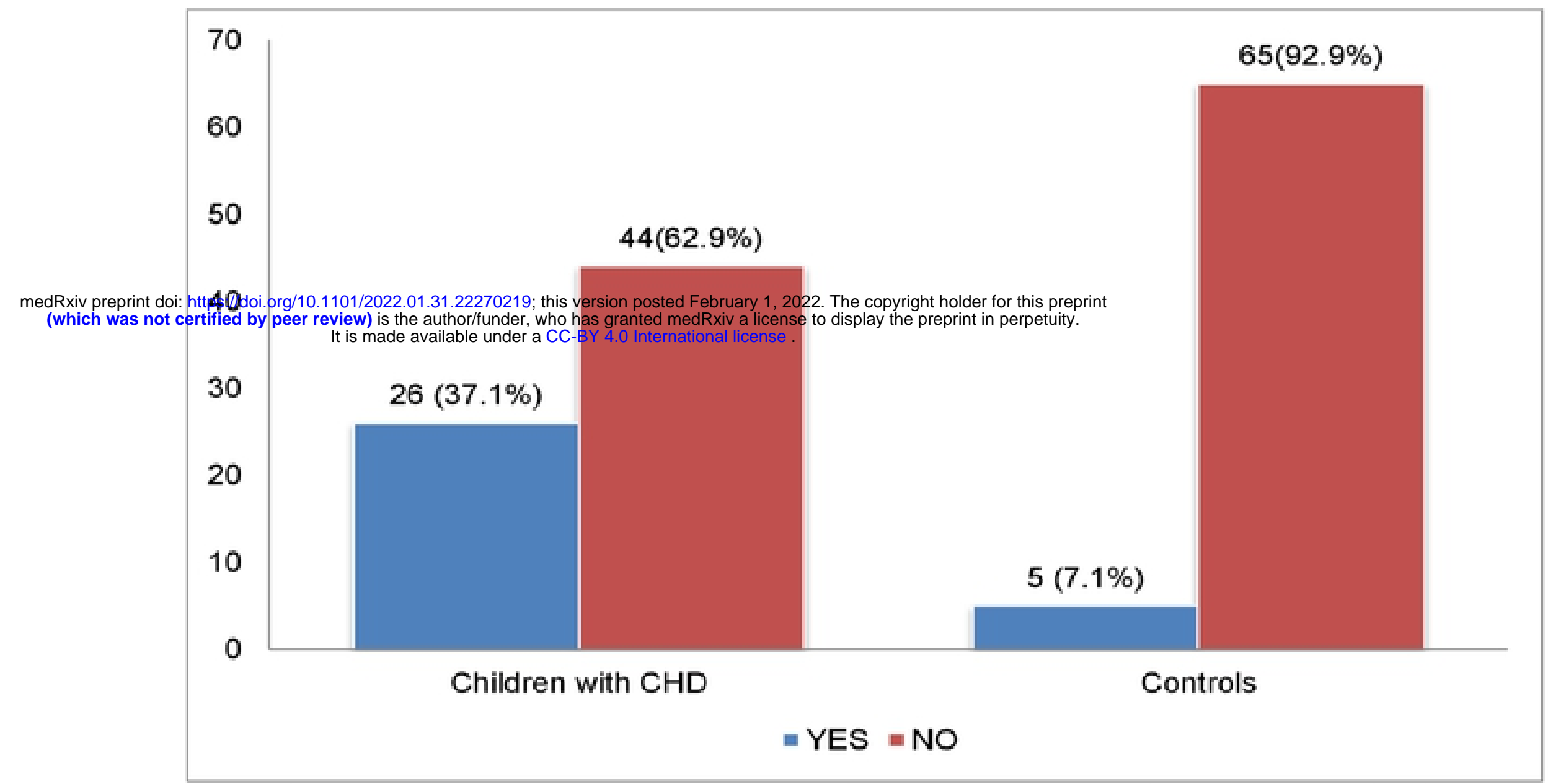

Fig 1. Prevalence of coagulation abnormalities in children with uncorrected CHD and controls 